\title{
CATCH AND EFFORT INFORMATION FOR ALBACORE TUNA (THUNNUS ALALUNGA) BY INDONESIA'S LONGLINERS OPERATING FROM BENOA
}

\author{
Lilis Sadiyah ${ }^{1}$, Budi Nugraha ${ }^{2}$ and Agustinus Anung Widodo ${ }^{1}$ \\ 1 Research Center for Fisheries Management and Conservation (RCFMC) \\ 2 Research Institute for Tuna Fisheries (RITF) \\ Received October 01-2012; Received in revised form May 20-2013; Accepted May 31-2013 \\ email: lilis sadiyah@yahoo.com
}

\begin{abstract}
Albacore (Thunnus alalunga - ALB) catch was the second highest tuna landed at Benoa Fishing Port and they are mostly landed as frozen bycatch. This paper attempts to provide information on ALB catch and effort trends by Benoa based longline vessels collected by the Benoa Port-based Catch Monitoring and Scientific Observer Programs. The ALB catch landed the Benoa Fishing Port in 2010 was estimated by the Research Institute for Tuna Fisheries (RITF) to be about 983.14 tons, whereas based on the Indonesian Tuna Long Line Association (ATLI), ALB catch landed at Benoa Fishing Port in 2010 amounted of 2,715.42 tons. This discrepancy was due to sampling for frozen catch (including ALB) could not be conducted in some companies and also there was one company that sell their catch direct to the collector. The observed longline sets were concentrated within the area between $10^{\circ}-20^{\circ} \mathrm{S}$ and $105^{\circ}-120^{\circ} \mathrm{E}$. Since 2008 , the observed setting positions have never extended to south of $20^{\circ} \mathrm{S}$. The higher catch rates of ALB were in area south of $15^{\circ} \mathrm{S}$.
\end{abstract}

\section{KEYWORDS: Albacore tuna, longline, Indian Ocean, Benoa}

\section{INTRODUCTION}

In the Indian Ocean, albacore (ALB) tuna (Thunnus alalunga) are mostly caught by longline (83-99\%), followed by purse seine (2\%) and other gears (pole and line, gill net, hand line, and troll line), except in the period of 1986-1991 when gill netting accounted for large catches before its operation was banned worldwide (Nishida \& Tanaka, 2008). Catch of ALB by Indonesian longline fleets operating in the Indian Ocean from 2004 to 2006 was estimated at 9,081 tons by the IOTC, $53.4 \%$ of which was landed at Benoa Fishing Port (Proctor et al., 2007). The estimates of landings for 2008 at Benoa Fishing Port for ALB was 2,913 tons (Prisantoso et al., 2009). Based on data from Indonesia Tuna Long Line Association or Asosiasi Tuna Longline Indonesia (ATLI) in 2011, ALB catch was the second highest tuna landed at Benoa Fishing Port, after bigeye tuna (BET), i.e. $31.19 \%$ of $8,707.33$ tons tuna landed. They are mostly landed as frozen bycatch and individual fish weights or length measurements are not taken (Prisantoso et al., 2009). More than $99 \%$ of ALB landed in Benoa Fishing Port between 2005 and 2006 was classified as bycatch (Proctor et al., 2006, Proctor et al., 2007). Indonesia's market for ALB is mainly Sweden (53.4\%), Italy (18.7\%), Poland (17.8\%) and Japan (10\%) (Davis \& Andamari, 2003). From the total exported ALB from Bali in 2001, ALB were only exported as frozen whole (64\%) and frozen loin (36\%) product (Davis \& Andamari, 2003).
Benoa Fishing Port (Bali), Muara Baru Port (Jakarta) and Cilacap Port (Central Java) are the most landing ports for tuna caught by the Indonesian industrial fleet operating in the Indian Ocean (Proctor et al., 2003). In addition, Banda Aceh (northern Sumatra), Padang - Bungus (central west coast Sumatra), Pelabuhanratu (western Java), Prigi (eastern Java), Kedonganan and Jimbaran (southern Bali), Ende (southeast Flores), and Kupang (southwest West Timor) are significant non-industrial landing places for tuna in the Indian Ocean (Proctor et al., 2003). Troll, purse seine and drift gillnet are the main fishing gears for Indonesian artisanal fisheries catching tuna and tuna-like species (Proctor et al., 2003). However, Benoa Fishing Port contributes more than $60 \%$ of Indonesian tuna catch (Satria et al., 2011).

An integrated Port-based Catch Monitoring Program at three major Indonesian ports, where tuna and billfish caught by longline fleets operating in the Indian Ocean are landed and processed, was established in the mid-2002 (Prisantoso et al., 2009). This was a collaborative research program between Indonesia's Research Centre for Capture Fisheries/ Research Institute for Marine Fisheries (RCCF/RIMF) and Directorate General for Capture Fisheries (DGCF), CSIRO Marine and Atmospheric Research, Australia's Department of Agriculture of Fisheries and Forestry (DAFF), Australian Centre for International Agricultural Research (ACIAR), Indian Ocean Tuna Commission (IOTC) and Overseas Fisheries Cooperation Foundation of Japan (OFCF) (Prisantoso et al., 2009). 
The aims of this monitoring program was to monitor the catches of all tuna species landed, and also to record the number of landings by Benoa-based longline vessel (hereafter, "landings" refers to the number of landings by Benoa-based longline vessel) (Davis et al., 2003, Proctor et al., 2006). This extended the earlier RCCF/RIMF/CSIRO monitoring program initiated in 1993 which fully focussed at Benoa Fishing Port (Davis \& Andamari, 2002). In February 2010, the RIMF commenced to undertake the sampling, collecting and monitoring activities (Nugroho et al., 2010).

The port-based monitoring program has resulted in good information on catch information (catch composition and length frequency) and vessel landing activity. This information was provided to the Indian Ocean Tuna Commission (IOTC) and Commission for the Conservation of Southern Bluefin Tuna (CCSBT). However, the monitoring program could not provide effort information for the fishery.

Indonesia began to develop a trial observer program for the industrial tuna longline fishery based at Benoa Fishing Port, Bali, in late 2005 , to address the shortage of CPUE information, and as a preliminary step to a broader observer program (see Sadiyah et al., 2007). This program is a collaboration between Indonesia's Ministry of Marine Affairs and Fisheries (MMAF) through the Research Centre for Capture Fisheries (RCCF), and CSIRO Marine and Atmospheric Research (Australia), and is funded by the Australian Centre for International Agricultural Research (ACIAR) (project FIS/2002/074: Capacity development to monitor, analyze and report on Indonesian tuna fisheries) (http://www.aciar.gov.au/ project/FIS/2002/074). This trial program was designed to produce accurate catch and effort data from Indonesia's Indian Ocean industrial tuna longline fishery based at Benoa, and also to provide detailed information in terms of fishing activities and environmental conditions. Since 2011, the Port-based Catch Monitoring Program and the Scientific Observer Program (hereafter, "Observer Program" refers to the Scientific Observer Program) have been undertaken under Research Institute for Tuna Fisheries (RITF) (which was established in 2011). This paper attempts to provide information on ALB catch and effort trends by Benoa based longline vessels collected by the Benoa Port-based Catch Monitoring and Scientific Observer Programs.

\section{MATERIALS AND METHODS}

Data collected by the Benoa Port-based Catch Monitoring and Observer Programs were analysed within this paper. Tuna catch landed at Benoa Fishing Port were monitored at fourteen processing plants where tuna landings are processed. $30 \%$ coverage of landings at each processing plant was set as a target coverage. The Benoa Port-based Catch Monitoring Program data collected from those processors in 2010 are presented. Whereas for the Observer Program, catch and effort data collected by the observers between 2005 and 2010 are presented.

\section{RESULTS}

\section{Benoa Port-based Catch Monitoring Program Data}

The number of landings and the number of boat sampled in 2010, by month, are presented in Figure 1. Both number of landings and number of boat sampled in 2010 peaked between June and July (Figure 1). Although sampling activities in 2010 commenced in February (Figure 1), there is no ALB to be sampled in that month. Total number of ALB sampled by the Benoa-port based Catch Monitoring program in 2010 was 22,648 fish (Figure 2) or 348.55 tons. The number of ALB samples taken in 2010 varied between months, with the highest number of samples was taken in May (Figure 2). Similarly, the estimated ALB catch landed (in weight) in 2010 varied between months and peaked in May (Figure 3 ). The ALB catch landed at the Benoa Fishing Port in 2010 was estimated by RITF to be about 983.14 tons (Figure 4). The estimated landings of BET and YFT were higher over time, followed by ALB and then SBT (Figure 4).

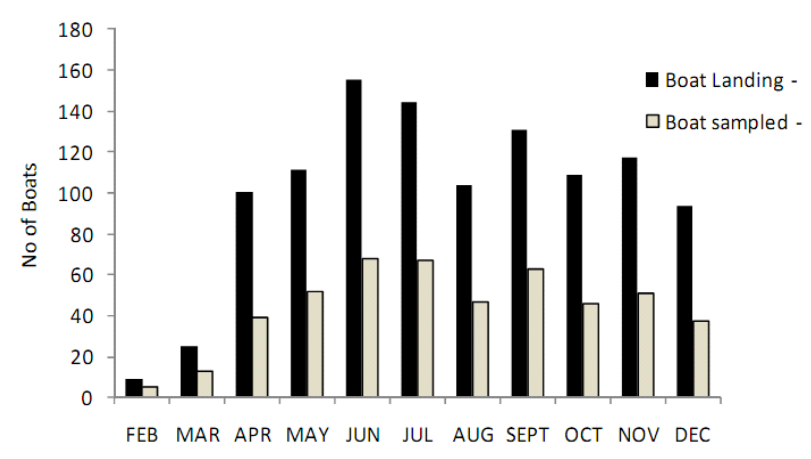

Figure 1. Monthly boat landings and sampling activities in 2010 (This figure was presented in Satria et al. (2011)) 


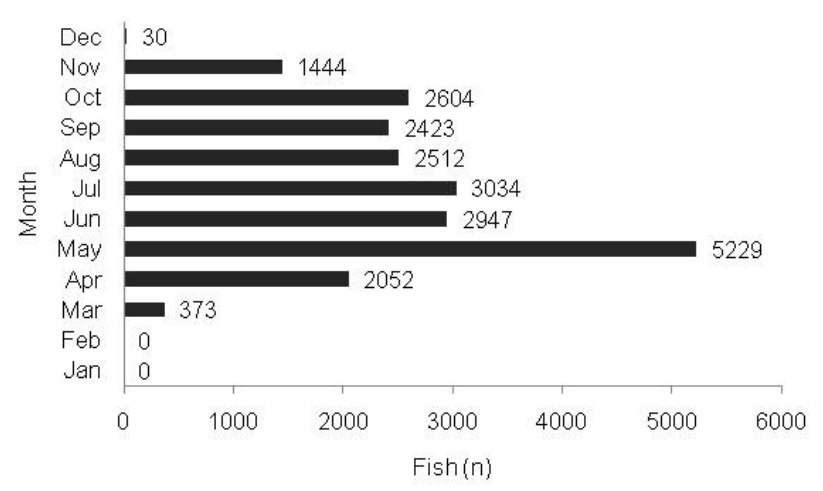

Figure 2. Number of ALB sampled in 2010

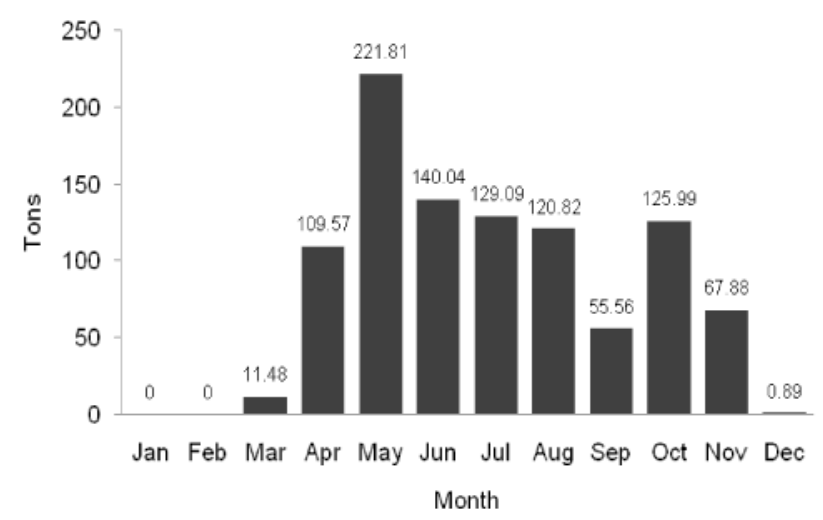

Figure 3. Estimated catch of ALB landed at Benoa Fishing Port in 2010 by month.

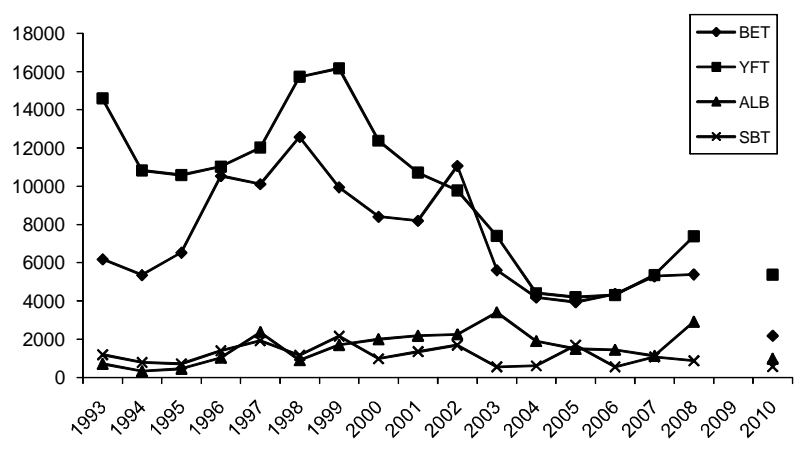

Figure 4. Estimated landings (in tons) of BET, YFT, ALB and SBT from Benoa-based longliners (modified from Davis et al. (2003), Proctor et al. (2007), Prisantoso et al. (2008) and Prisantoso et al. (2009)). Data 2009 could not be presented as there was a problem in the database.

\section{Observer Program Data}

The number of observer decreased from 6 to 5 observers in 2008 (Table 1). The number of trips by the observers ranged between 6 and 19 trips and the number of tuna fishing companies voluntarily involved in the Observer Program increased from 1 in 2005 to 8 companies in 2009, but then decreased to 4 companies in 2010 (Table 1). Total days at sea decreased in 2010 to half of that in 2009 , but the average number of days/trip was higher in 2010 (Table 1).

Table 1. Activity summary of observer based at Benoa Fishing Port (this Table was presented in Satria et al. (2011)).

\begin{tabular}{ccccccc}
\hline Year & $\begin{array}{c}\text { No. of } \\
\text { Observers }\end{array}$ & No. of Trips & $\begin{array}{c}\text { No. of } \\
\text { Companies }\end{array}$ & $\begin{array}{c}\text { Total Days at } \\
\text { Sea }\end{array}$ & Days/trip & $\begin{array}{c}\text { Average } \\
\text { Days/Trip }\end{array}$ \\
\hline 2005 & 6 & 6 & 1 & 251 & $19-22$ & 20 \\
2006 & 6 & 19 & 5 & 758 & $7-99$ & 39 \\
2007 & 6 & 14 & 5 & 648 & $21-108$ & 34 \\
2008 & 5 & 15 & 7 & 481 & $23-66$ & 30 \\
2009 & 5 & 14 & 8 & 535 & $15-59$ & 38 \\
2010 & 5 & 8 & 4 & 240 & $40-50$ & 50 \\
\hline
\end{tabular}

Observed fishing positions included the Eastern Indian Ocean between latitudes $0^{\circ}$ and $34^{\circ} \mathrm{S}$ and longitudes $75^{\circ}$ and $132^{\circ} \mathrm{E}$, but also the Banda Sea (Figure 5). The observed longline sets were concentrated within the area between $10^{\circ}-20^{\circ} \mathrm{S}$ and $105^{\circ}-120^{\circ} \mathrm{E}$. The furthest distance of these sets occurred in 2006 and 2007. Since 2008, the observed setting positions have never extended to south of $20^{\circ} \mathrm{S}$.
The total number of observed hooks decreased from about 645,000 hooks in 2006 to less than 280,000 hooks in 2010, with the peak occurred in 2006 (Figure 6). Trends in the recorded BET, YFT and SBT catch by year mostly reflected the annual effort pattern, whereas the recorded ALB catch peaked in 2008 (Figure 6). ALB catch peaked in 2008, i.e. more than 1,700 fish. Between 2006 and 2008, the ALB catch was higher than the other three tuna species. The ALB catch then dropped to less than half of that in 2008. 


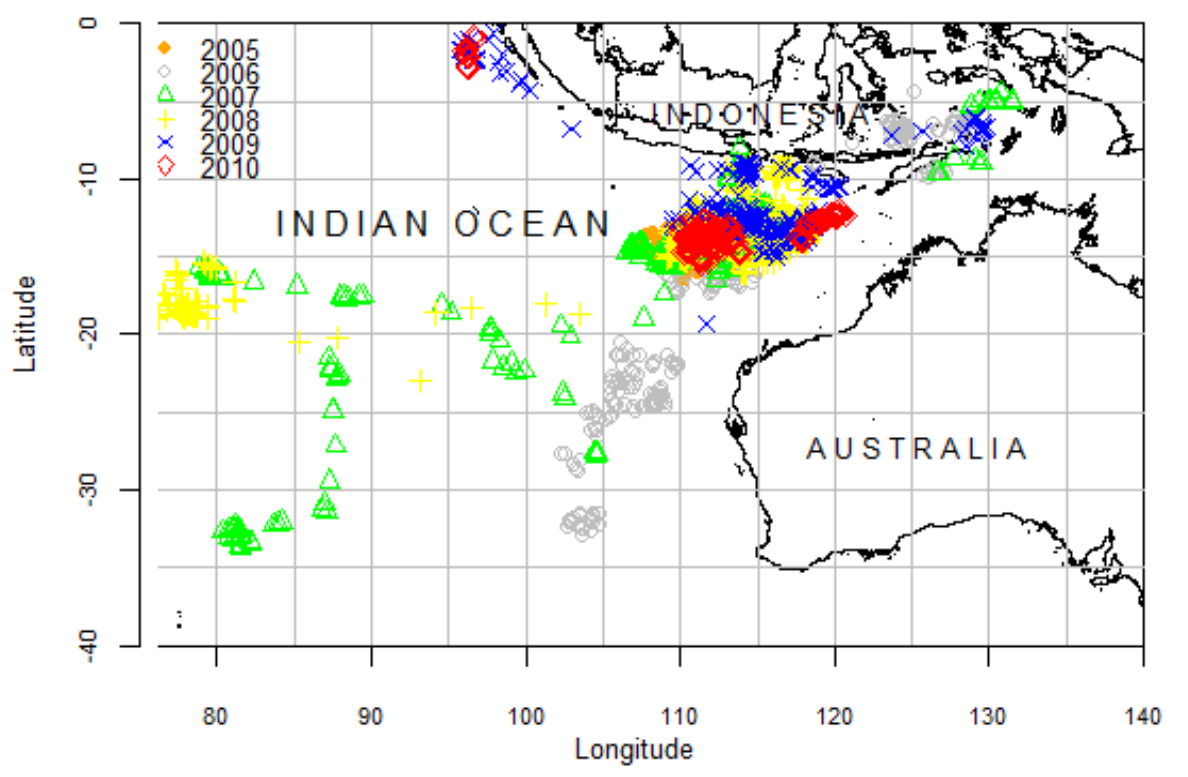

Figure 5. Spatial distributions of the observed sets from 2005 to 2010

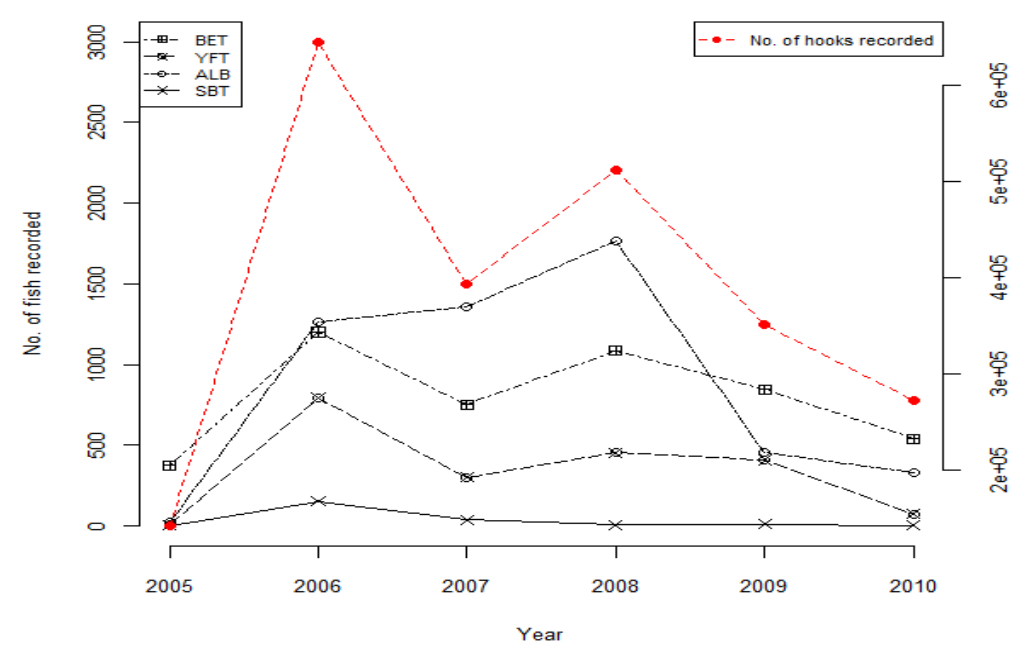

Figure 6. Number of fish and number of hooks recorded by observers per year

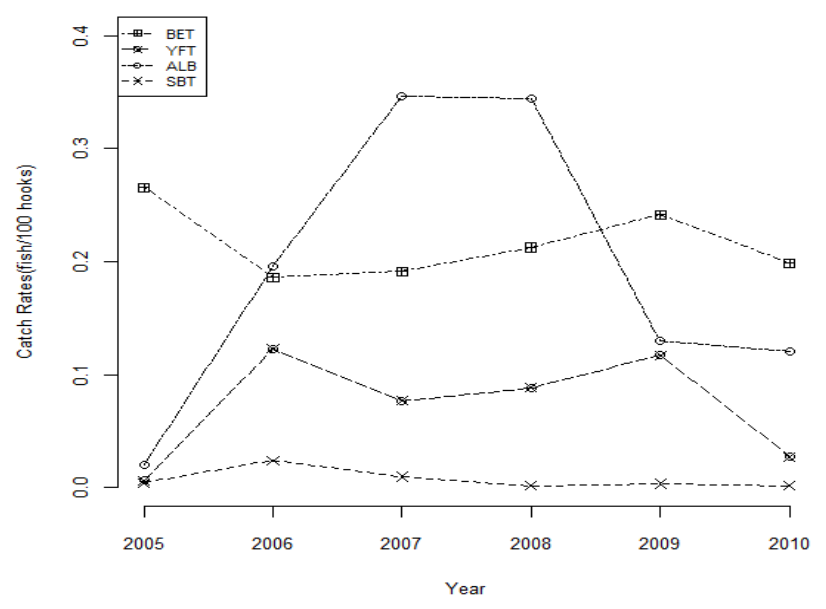

Figure 7. Nominal CPUE by year for BET, YFT, ALB and SBT recorded by observers
CPUEs for ALB and BET were highest between 2006 and 2008 (for ALB), and in 2005, 2009 and 2010 (for BET), followed by YFT and then SBT with the lowest CPUEs (Figure 7). ALB CPUEs ranged between 0.02 and 0.35 fish/100 hooks. ALB had higher catch rates in area south of $15^{\circ} \mathrm{S}$ (Figure 8). The highest ALB catch rates ( $>1$ fish/100 hooks) occurred in the area between $30^{\circ}-35^{\circ} \mathrm{S}$ and $80^{\circ}$ $85^{\circ} \mathrm{E}$. 


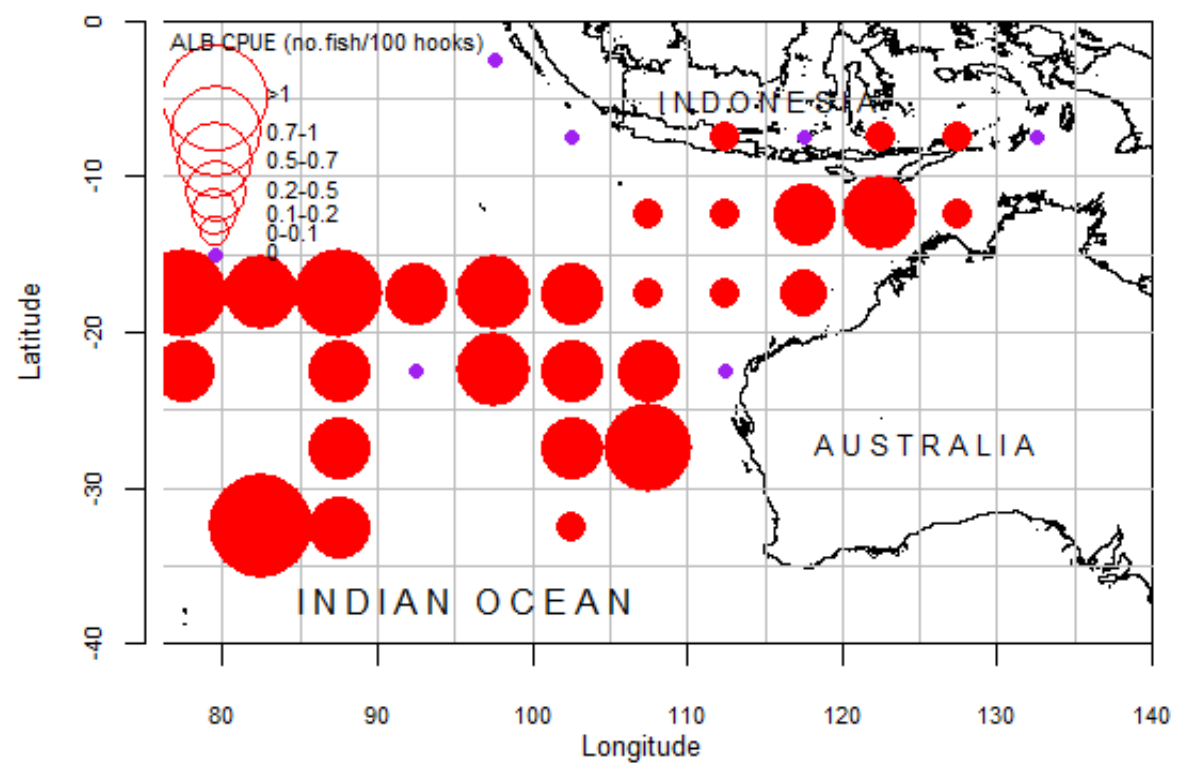

Figure 8. Spatial distribution of nominal CPUEs (no. fish/100 hooks) for ALB recorded by Benoa Observer, aggregated from 2005 to 2010.

\section{DISCUSSION}

Based on data from ATLI, ALB catch landed at Benoa Fishing Port in 2010 amounted of 2,715.42 tons (Figure 9). The estimated ALB catch landed by RITF was smaller than the ALB catch landed reported by ATLI, this was due to sampling for frozen catch (including ALB) could not be conducted in some companies and also there was one company that sell their catch direct to the collector. This is one of problems currently faced by RITF in monitoring catch landed at the Benoa Fishing Port. Based on ATLI, ALB catch landed at the port in 2010 was in similar proportion with BET and yellowfin tuna (YFT) (Figure 10). The ALB catch peaked in 2008 between 2005 and 2010 (Figure 10).

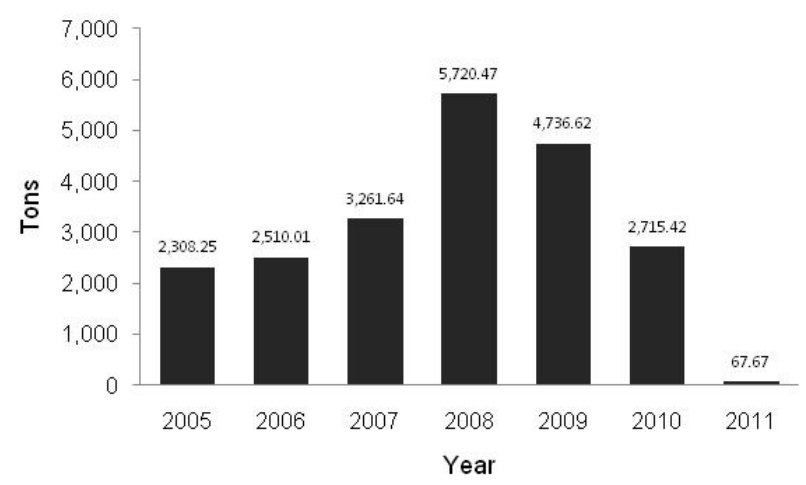

Figure 9. ALB catch landed at Benoa Fishing Port by year from 2005 to 2011 (2011 catch was total catch from January up to March 2011) (Source: ATLI, 2011).

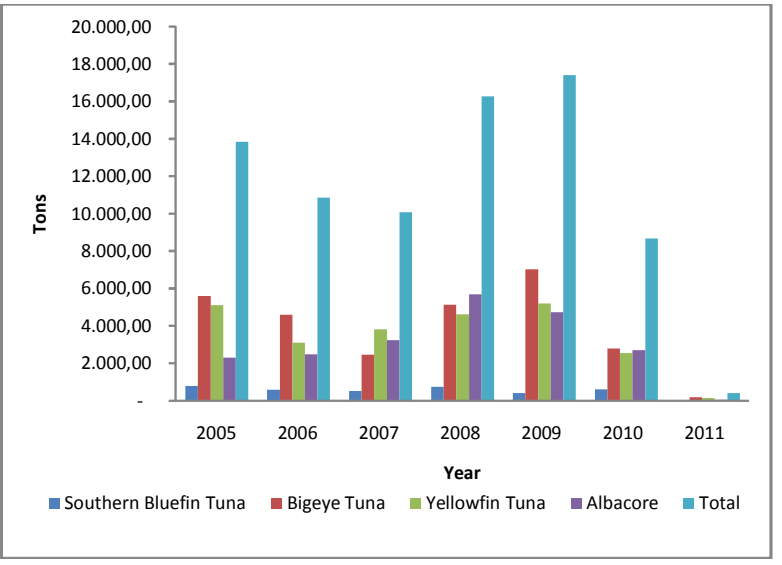

Figure 10. Catch of SBT, BET, YFT, ALB and total tuna, landed at Benoa Fishing Port by year from 2005 to 2011 (2011 catch was total catch from January up to March 2011) (Source: ATLI, 2011).

The Observer Program data set is currently the most detailed and most reliable data available from the fishery, in providing catch and effort information that would allow an improved understanding of the fishery. The detail information recorded by the Observer Program allows a comprehensive CPUE standardisation to be undertaken. As such, the continuation of the Observer Program is essential. In addition, it is recommended that the fleet coverage (in terms of area coverage and the number of companies involved) is increased. 


\section{CONCLUSION}

Mostly albacore tuna were caught by tuna long line that accounted $83-99 \%$ of the national albacore tuna catch, peak season experienced in May in the year 2010. The percentage of albacore tuna was about $15-35 \%$ of total tuna caught by tuna long line landed at Benoa. Albacore tuna CPUEs ranged between 0.02 and 0.35 fish $/ 100$ hooks and it had higher catch rates in area south of $15^{\circ} \mathrm{S}$. The highest catch rates $(>1$ fish $/ 100$ hooks) occurred in the area between $30^{\circ}$. $35^{\circ} \mathrm{S}$ and $80^{\circ}-85^{\circ} \mathrm{E}$.

\section{ACKNOWLEDGEMENTS}

The authors wish to thank Indonesia's tuna fishing companies and the Bali Office of WASKI for their cooperation, assistance and support for the Portbased Catch Monitoring program and Observer program. We acknowledge the support from the scientific enumerators and observers in RITF, Benoa, Bali, without them this research would not have been possible. We also would like to thank ACIAR and RCCF for their funding through research collaboration in the project FIS/2002/074: Capacity development to monitor, analyse and report on Indonesian tuna fisheries.

\section{REFERENCES}

Davis, T. L. O. \& Andamari, R. 2002. Catch monitoring of the fresh tuna caught by the Bali-based longline fishery in 2001. CCSBT 7th Scientifc Meeting, Canberra, Australia, 9-11 September 2002. CCSBT-SC/0209/24.

Davis, T. L. O. \& Andamari, R. 2003. Analysis of 2001 dinas export packing list data by species, product and destination. CCSBT Indonesian Catch Monitoring Review, Queenstown, New Zealand, 1011 April 2003. CCSBT-ICM/0304/7.

Davis, T. L. O., Farley, J. H. \&Andamari, R. 2003. Monitoring the longline catch of SBT landed in Indonesia 20022003: final report. Hobart, Tas., CSIRO Marine Research.

Nishida, T. \& Tanaka, M. 2008. General reviews of Indian Ocean albacore (Thunnus alalunga). Second Session of the IOTC Working Party on Temperate Tunas, Bangkok, Thailand, 1 November 2008. IOTC-2008-WPTe-INF03.

Nugroho, D., Satria, F. \& Nugraha, B. 2010. National report Indonesia southern bluefin tuna fishery. CCSBT 15th Meeting of the Extended Scientific Committee, Taipei, Taiwan, $4-10$
September 2010. CCSBT - ESC/1009/SBT FISHERIES - Indonesia.

Prisantoso, B. I., Andamari, R. \& Proctor, C. 2008. The catch of SBT by the Indonesian longline fishery operating out of Benoa, Bali in 2007. CCSBT 5th Management Procedure Workshop and the 13th Meeting of the Extended Scientific Committee, Rotorua, New Zealand, 2-10 September 2008 and 5-12 September 2008.

Prisantoso, B. I., Andamari, R. \& Proctor, C. 2009. The catch of SBT by the Indonesian longline fishery operating out of Benoa, Bali in 2008 CCSBT 14th Meeting of the Scientific Committee (incorporating the Extended Scientific Committee), Busan, Korea, 5 - 11 September 2009. CCSBT-ESC/0909/SBT Fisheries - Indonesia.

Proctor, C., Andamari, R., Retnowati, D., Prisantoso, B. I., Poisson, F., Herrera, M. \& Fujiwara, S. 2007. The catch of SBT by the Indonesian longline fishery operating out of Benoa, Bali in 2006. CCSBT 8th Meeting of the Stock Assessment Group and the 12th Meeting of the Extended Scientific Committee, Hobart, Australia, 4-8 September 2007 and 10-14 September 2007.

Proctor, C. H., Andamari, R., Retnowati, D., Herrera, M., Poisson, F., Fujiwara, S. \& Davis, T. L. O. 2006. The catch of SBT by the Indonesian longline fishery operating out of Benoa, Bali in 2005. CCSBT 7th Meeting of the Stock Assessment Group and the 11th Meeting of the Extended Scientific Committee, Tokyo, Japan, 4-11 September and 12-15 September 2006.

Proctor, C. H., Merta, I. G. S., Sondita, M. F. A., Wahju, R. I., Davis, T. L. O., Gunn, J. S. \& Andamari, R. 2003. Areview of Indonesia's Indian Ocean tuna fisheries. ACIAR Country Status Report. $106 \mathrm{p}$.

Sadiyah, L., Andamari, R., Prisantoso, B. I., Retnowati, D., Proctor, C. \& Davis, T. L. O. 2007. Trial observer program for Indonesia's tuna longline fishery in the Indian Ocean CCSBT 8th Meeting of the Stock Assessment Group (SAG8) and the 12th Meeting of the Extended Scientific Committee (ESC12) Hobart, Australia, 4-8 September and 1214 September 2007. CCSBT-ESC/0709/Info04.

Satria, F., Wudianto, Nugroho, D., Sadiyah, L., Nugraha, B., Barata, A. \& Suryanto. 2011. National report Indonesia southern bluefin tuna fisheries. Bali, Benoa, 19 - 28th July 2011. CCSBT - ESC/ 1107/SBT FISHERIES - Indonesia (revised). 